\title{
Declarations of Invalidity in Superior Courts
}

\section{Mark Mancini*}

Section 52(1) of the Constitution Act, 1982 empowers courts to declare unconstitutional laws that are inconsistent with the Constitution "to the extent of their inconsistency." Section 52 is a powerful tool in the hands of judges. For example, a claimant need not be directly affected by an unconstitutional law to raise a challenge to that same law, ${ }^{2}$ and once a court declares a law invalid under section 52, the law is effectively removed from the statute books. ${ }^{3}$

A key question is whether such a declaration, issued by one judge of a multi-member lower court, binds another judge of that same court. This penomenon an boadly described as "horizontal stare decisis." ${ }^{4}$ But the Supreme Court has only explored horizontal stare decisis in the context of revisiting its own decisions. ${ }^{5}$ It has never opined on whether there is something special about horizontal stare decisis in lower courts, especially involving constitutional declarations under section 52; spefically, whether one judge is bound by another judge's declaration of invalidity. This issue was directly confronted in the McCaw case at the Ontario Superior Court. ${ }^{6}$ Faced with a previous section 52 declaration of invalidity issued against section 33.1 of the Criminal Code, Spies J found that she was bound by that declaration. Accordingly, she found section 33.1 unconstitutional.

In this short paper, after reviewing the salient facts of McCaw, I argue that Spies J's ruling is broadly consistent with Supreme Court constitutional remedies doctrine, which is basically formalist in nature and permits no discretion on the part of judges to depart from the binding effect of a section 52 remedy. I then deal with two objections to this position. Ultimately, while one can question the coherence of the Supreme Court's doctrine, McCaw represents a defensible application of it.

\section{Facts}

Section 33.1 of the Criminal Code ${ }^{7}$ was Parliament's response to the Supreme Court of Canada's decision in Daviault. ${ }^{8}$ In that decision, the Court concluded that a defence of extreme intoxication was available to criminal defendants. In July 1995, in response to outcry, section 33.1 of the Criminal Code was enacted by Parliament. Section 33.1 barred criminal defendants from raising a defence of extreme intoxication in cases that involve assault - socalled general intent mens rea offences. It did not oust the common law availability of the defence in cases of mens rea specific intent offences - for example, murder.

Since the adoption of section 33.1, the Ontario courts have struggled with its constitutionality. In $\mathrm{McCaw}$, the Court noted that counsel raised nine reported decisions in which the constitutionality of section 33.1 was addressed; seven of the cases involved superior courts of justice in the various provinces. ${ }^{9}$ All of the cases found section 33.1 to infringe sections 7 and 11(d) of the Charter, with the courts differing on whether the infringements could be saved under section 1 of the Charter. Specifically, the Ontario courts had dealt with the matter a number of times. In 1998, in Decaire, ${ }^{10}$ the Ontario Superior Court concluded that section 33.1 could be saved by 
section 1. In 1999, the court in Dunn ${ }^{11}$ concluded the opposite, finding that section 33.1 infringed sections 7 and 11(d) of the Charter in a manner unjustified under section 1 . Three more cases since Dunn concluded that section 33.1 could not be saved by section $1 .^{12}$

Against this background, Spies J began the analysis on remedy by noting that the previous cases (including Dunn) had not been appealed on remedy - as such, the Ontario Court of Appeal did not opine on the issue. ${ }^{13}$ This left the main question: was Spies J bound in this case by Dunn and its progeny? The applicant McCaw argued that she was so bound. He argued that "... when a court of competent jurisdiction declares a provision invalid pursuant to s. 52 of the Constitution Act, the constitutionality of the provision is no longer a live issue, and the declaration renders the provision of no force and effect in that province." ${ }^{14}$ It is not a principle of judicial comity that is binding, but rather, section 52 itself. ${ }^{15}$ The respondent countered that one judge of the Superior Court "lacks the authority" to strike down section 33.1 so that it would be binding on other judges of the same court. ${ }^{16}$ The respondent advocated a weak form of horizontal stare decisis. ${ }^{17}$

Spies J ultimately concluded that the Supreme Court's decision in Ferguson was binding on her. Ferguson specifically rejected the possibility of individual constitutional exemptions from otherwise unconstitutional laws, ${ }^{18}$ instead holding that unconstitutional laws are forever removed from the statute books. ${ }^{19}$ She distinguished her conclusion from other cases ${ }^{20}$ that framed the issue as one of judicial comity:

\footnotetext{
If a judge of this Court finds that a provision of a statute is unconstitutional, by virtue of $s$. 52 of the Constitution Act and Ferguson, that provision is invalid for all future cases - it is "off the books." Coming to this conclusion does not require a consideration of judicial comity. In my view, the question of judicial comity has no relevance to the issue before me. ${ }^{21}$
}

Since Spies J considered herself bound by Dunn and the section 52 declaration of invalidity issued in that case, she concluded that section 33.1 was unconstitutional and should be declared invalid and of no force and effect.

\section{Consistency with established doctrine}

In the law of constitutional remedies, there is a tension between formalism and flexibility. On one hand, courts are understandably concerned with the doctrinal reach of remedies they issue. Those affected by unconstitutional laws should receive the benefit of the remedy. On the other hand, a strictly formalist account could expand the reach of remedies at the price of flexibility. A class of claimants could be temporarily denied a remedy in order to allow the government time to fashion a better legislative response, or to wait for a case in which a more directly affected party comes before the court.

The issue faced by Spies J tracks this concern. On one hand, there is the basic idea of the rule of law: no one should be subject to an unconstitutional law. ${ }^{22}$ If a subsequent judge of a coordinate court can depart from a previous declaration of invalidity, and conclude that on the facts before her the law is constitutional, there is a chance that the claimant could be subject to a law that is unconstitutional in many other respects. But on the other hand, there is the difficult issue of flexibility. New facts beget new law. Appeal courts could benefit from diverse opinions "percolating" in lower courts that differ on the constitutionality of a particular law..$^{23}$

While both views are feasible, the Supreme Court's precedents prize the rule of law-formalist concern over remedial flexibility. Under those cases, a law is unconstitutional once a court says so, because that declaration triggers the independent operation of section 52. Logically, the same mandate applies to a subsequent judge faced with a previously binding section 52 declaration. As an analogue to the rule of law, that subsequent judge cannot apply an unconstitutional law, and must consider it unconstitutional reaching forwards and backwards. In McCaw, Spies J was duty bound to apply the holding in Dunn as a matter of constitutional law.

The distinction between section 52 and section 24 remedies is the starting point for this argument. The Court has held that cognizable 
unconstitutional challenges come in two types: problems with laws, and problems with governmental acts. ${ }^{24}$ The former invite a remedy under section 52, such as a declaration of invalidity, whereas the latter invite a remedy under section $24(1)$, such as personal declarations or damages. ${ }^{25}$ Remedies under both categories will rarely, if ever, be combined.$^{26}$ To the Court, then, an unconstitutional law (as opposed to an act) must be solved systemically, so that any remedy attaches to persons similarly situated to the claimant. As noted above, this is reinforced by the Court's standing doctrine as it pertains to challenging a government law; claimants can attack the constitutionality of a law, even if they do not benefit from a right, assuming they can prove an infringement in the case of third parties. ${ }^{27}$ Under section 52, then, courts must declare laws that are inconsistent with the Constitution invalid systemically - no discretion is conferred otherwise. ${ }^{28}$ When a court does so, the effect of the declaration reaches fully backwards and forwards - the law never existed, and will not exist going forward. As the Court noted in Hislop, in the ordinary case, a declaration of invalidity says that the law was always unconstitutional from the time of its enactment. ${ }^{29}$ This is an attempt by the court to "remedy unconstitutional states of affairs that took place prior to the date of judgment." ${ }^{30}$ At the same time, declarations can also be prospective, in the sense that the law no longer exists, and future citizens will not be subject to it. ${ }^{31}$ This necessarily arises from the supremacy of the Constitution and the rule of law. A law that is unconstitutional cannot be enforced going forward, because to do so would subject persons to an unconstitutional law. ${ }^{32}$ While some have described prospective rulings as a "radical departure" from the common law basis of remedies as retroactive, in reality, prospective rulings are a direct analogue to the supremacy of the Constitution because they relieve citizens of the responsibility of being subject to an unconstitutional law. ${ }^{33}$ It is apt, therefore, to speak of section 52 having independent meaning. As the Court noted in Martin:

The invalidity of a legislative provision inconsistent with the Charter does not arise from the fact of its being declared unconstitutional by a court, but from the operation of s. 52(1). Thus, in principle, such a provision is invalid from the moment it is enacted, and a judicial declaration to this effect is but one remedy amongst others to protect those whom it adversely affects. In that sense, by virtue of s. 52(1), the question of constitutional validity inheres in every legislative enactment. Courts may not apply invalid laws, and the same obligation applies to every level and branch of government... ${ }^{34}$

Put differently, once a law is rendered unconstitutional by a court, it is invalid going backwards and forwards. The law applies to pending ${ }^{35}$ causes of actions arising before the date of judgment, and to any causes of action arising after the date of judgment, as then-Chief Justice McLachlin made clear in Ferguson.

The same is true in the case of McCaw. Section 33.1 provided a limited defence of extreme intoxication to defendants. It ousted the common law defence of extreme intoxication, and altered it so that only a limited defence was available in cases of specific intent. The Dunn case issued a declaration of invalidity, which on the Supreme Court's understanding of the law, effectively removed section 33.1 from the statute books. As such, after Dunn, the full common law defence of extreme intoxication was available to defendants. When McCaw came about, Spies J was bound by that declaration because it applied to any causes of action still in the system when Dunn was rendered, and going forward aft er Dunn; McCaw fell in this latter category. As noted in Martin, Spies J could not apply an unconstitutional law. She had, according to Ferguson, "no discretion" to do anything other but consider herself bound by Dunn.

According to the Supreme Court's own doctrine, section 52 has independent meaning that supersedes the particular declaration of a court. A court declaration merely triggers the operation of section 52. In this sense, it is not typical "horizontal stare decisis" or principles of comity that mandated the holding in McCaw. Once triggered by operation of law, section 52 invalidated statutes retrospectively and prospectively. Courts, who themselves are bound by the Constitution, cannot transgress it. As a result, 
the holding in $M c C a w$ is entirely predictable based on the Supreme Court's remedies doctrine.

\section{Criticisms}

There are two main criticisms, or glosses, that should be put on the above analysis. Note that, again, these are not criticisms of the Supreme Court's doctrine as such. Rather, these are criticisms that pertain to the implications drawn above: that the Supreme Court's doctrine mandates Spies J's ruling in McCaw. These criticisms include the Supreme Court's doctrine regarding suspended declarations and the federalism implications of the analysis.

\section{Suspended declarations of invalidity}

Some might say that the advent of so-called "suspended declarations of invalidity" undermines the idea that a subsequent court is bound by a previous court's declaration of unconstitutionality. If a court has no discretion under section 52, how could a court then give an unconstitutional statute temporary validity? If this domino falls - if there is some discretion not to apply section 52 - then it raises the question of why a subsequent court, on different facts, should have to abide by a previous court's section 52 declaration.

However, on the contrary, the origins of a suspended declaration of invalidity are rooted in the same rule of law concerns as the holding in $\mathrm{McCaw}$, and demonstrate the mandatory nature of section 52. Thus, these two rules of constitutional remedies are not necessarily in conflict.

The Supreme Court introduced suspended declarations of invalidity in the Manitoba Reference. Suspended declarations of invalidity were seen as a direct response to the problem of a mandatory section 52 remedy taking retroactive and prospective effect, as in McCaw. The Court found that Manitoba's laws were required to be published in both official languages. It understood, under the circumstances, that " $[t]$ he only appropriate resolution ... is for the Court to fulfill its duty under s. $52 \ldots$ and declare all unilingual Acts of the Legislature of Manitoba to be invalid and of no force and effect ...." ${ }^{36}$
Similar to the situation in McCaw, the Court had no discretion to do otherwise - because " $[t]$ he words 'of no force or effect' mean that a law thus inconsistent with the Constitution has no force or effect because it is invalid." 37 This can be seen as the same automatic operation of section 52 endorse in McCaw and Ferguson.

But, the Court recognized that an immediate declaration of invalidity, reaching forwards and backwards, would invalidate all laws and acts taken under those laws in the province of Manitoba, creating a "legal vacuum." 38 This is because, in a retroactive sense, the "... rights, obligations and other effects which have arisen under the repealed, spent and current Acts of the Manitoba Legislature will be open to challenge, since the laws under which they purportedly arise are invalid and of no force and effect." 39 The declaration also operated prospectively, because it removed the "colour of authority" that Manitoba officials enjoyed under the impugned statutes, and it removed the statutes for the future. ${ }^{40}$ It also required that "from the date of this judgment, all new Acts of the Manitoba Legislature be enacted, printed and published in both French and English." ${ }^{41}$ If the declaration operated immediately, rights and obligations secured bylaw in the past would be thrown into question, and no legal regime would govern Manitoba.

The Court framed this concern in terms of the rule of law. By declaring the statutes invalid, an element of the rule of law would be sacrificed, the part that"requires the creation and maintenance of an actual order of positive laws which preserves and embodies the more general principle of normative order." 42 And because the rule of law required the maintenance of this order of laws, an immediate declaration according to section 52 - itself an analogue to the rule of law - would undermine it. The rule of law thus insisted on the temporary validity of the nullified statutes.

The operation of suspended declarations originally envisioned in the Manitoba Reference is consistent with later Supreme Court doctrine and $M c C a w$ for two reasons, alluded to above. First, the Manitoba Reference confirms that the 
operation of section 52 is automatic, with no discretion in the issuing court. The Court was forced to strike down the impugned statutes because, according to the law, it had no other choice. Thus, when the Court in Ferguson objects to constitutional exemptions, it does so because that remedy infuses discretion into remedial crafting under section 52 .

Second, and most importantly, the temporary declaration of invalidity on these grounds is not inconsistent with the fundamental basis of Supreme Court remedies doctrine: the rule of law. As noted above, it is because of the rule of law that a temporary declaration of invalidity became an option on the remedial menu. But, it is also the rule of law that demands the doctrinal results in Ferguson and Big M: no one should be subject to an unconstitutional law, because it is not a law at all. Temporary declarations are therefore consistent with this basis of Supreme Court doctrine if framed as a matter of the rule of law.

Where the situation becomes more difficult is in the later extension of the doctrine of temporary validity to other situations: for example, situations where benefits may be denied to a group through the declaration of invalidity. ${ }^{43}$ Here, the connection to the rule of law becomes more tenuous. There may be daylight between McCaw and these sorts of cases. But to the extent the Court abides by the original meaning behind the suspended declaration, there is no doctrinal inconsistency.

\section{Federalism Implications}

In $\mathrm{McCaw}$, the declaration of invalidity only applied in the province of Ontario. ${ }^{44}$ Section 96 courts, operating within the province, only have powers within the province, so that courts of one province are not bound by courts of another province. ${ }^{45}$ Ostensibly, this applies to federal statutes. A provision of a federal statute could be formally unconstitutional in one province but not another. The question is: does it not undermine the systemic nature of section 52 remedies for courts in one province to disregard rulings in other provinces regarding the same federal statute?
At the root of this objection is a fundamental challenge to the division of powers provisions in the Constitution Act, 1867. Section 96 establishes federally-appointed courts within the provinces. The interaction between section 92(14) and sections $96-100$ is a balanced compromise between provincial authority over administration of justice and a federal appointing power of judges of the superior courts. ${ }^{46}$ Thus, while section 96 provides that the federal government appoints judges of the superior courts in the provinces - and thus ensures a basic uniformity among the provinces - superior courts are still "within the province."

It is erroneous to suggest that the Supreme Court's doctrine requires a section 52 remedy to run across provincial lines, because such a remedy is unknown to Canadian law, where legislative and judicial competence is split between orders of government. It would be an affront to the principled federalism balance established by the Constitution Act, 1867 to argue that section 52 declarations should extend throughout the country when issued by one judge in a province. The fact that there may be different findings between one province and another is a feature, not a bug, of the federalist system. Further, this does not undermine the systemic nature of section 52 declarations within the province. It is perfectly consistent to view section 52 remedies as systemic because, in our constitutional structure, the administration of justice is a provincial competence. Any variations in the constitutionality of laws across provincial boundaries is a necessary sacrifice to federalism with the concomitant operation of the systemic remedy in the province in which the court exercises formal jurisdiction. In short, the rule of law is maintained because systemic declarations within the province apply, subject to the restrictions of the law of the Constitution, which establish a federal-provincial division.

That said, other judicial principles can work in tandem with section 52 remedies to mitigate any inconsistencies. Principal among these is the idea of comity. For example, in Bergeron ${ }^{47}$ the Quebec Superior Court decided that it was not bound by a declaration of invalidity issued 
in Ontario. However, it did say that the Ontario precedent could be cited as non-binding precedent. Owing to the nature of constitutional supremacy, comity may dictate that declarations of invalidity issued in one province are highly persuasive in another province. This "softer" form of stare decisis prioritizes the principle of federalism that should be respected in constitutional remedies.

The point here is not that federalism is a criticism of the Supreme Court's doctrine. Rather, it is simply that the criticism misapprehends what a declaration of invalidity is in the first place. It cannot run across provincial boundaries owing to the division of powers. Thus, when one speaks of a systemic remedy, one speaks of it in the province. A national declaration of invalidity would not have been envisioned by the framers - or the current Supreme Court - because of the primacy of federalism.

\section{Conclusion}

The importance of McCaw should not be understated. At the heart of the matter is the tension in the law of constitutional remedies between flexibility and rule of law concerns. As noted above, the Supreme Court prizes the latter, and as a matter of vertical stare decisis, lower courts must follow suit. This puts the decision in $\mathrm{McCaw}$ in an understandable and defensible light. Of course, there may be good reasons why the Supreme Court's doctrine trades off the rule of law against flexibility concerns to an inappropriate degree. But as it stands, the strong-form version of section 52 embraced by the Supreme Court was perfectly represented in $\mathrm{McCaw}$, and is not clearly barred by other aspects of the Supreme Court's remedies doctrine.

\section{Endnotes}

* National Director, Runnymede Society; J.D. (UNB, 2017), LL.M. (Chicago, 2019).

1 Constitution Act, 1867 (UK), 30 \& 31 Vict, c 3, reprinted in RSC 1985, Appendix II, No 5.

$2 R$ v Big M Drug Mart Ltd, [1985] 1 SCR 295, 18 $\operatorname{DLR}\left(4^{\text {th }}\right) 321[$ Big $M]$.
$3 R v$ Ferguson, 2008 SCC 6 (" $[\mathrm{t}] \mathrm{o}$ the extent that the law is unconstitutional, it is not merely inapplicable for the purposes of the case at hand. It is null and void, and is effectively removed from the statute books" at para 65).

4 See Joseph J Arvay, Sheila M Tucker, \& Alison M Latimer, "Stare Decisis and Constitutional Supremacy: Will Our Charter Past Become an Obstacle to Our Charter Future?” (2012) 58 SCLR 61.

5 Canada (Attorney General) v Bedford, 2013 SCC 72 at para 39.

$6 R v$ McCaw, 2018 ONSC 3464 [McCaw].

7 Criminal Code, RSC 1985, c C-46.

$8 R v$ Daviault, [1994] 3 SCR 63, 118 DLR $\left(4^{\text {th }}\right) 469$.

9 McCaw, supra note 6 at para 30.

$10 R v$ Decaire, [1998] OJ No 6339 (Ct J) [Decaire].

$11 R v$ Dunn, [1999] OJ No 5452, 28 CR $\left(5^{\text {th }}\right) 295$ (Sup Ct) $[$ Dunn $]$.

$12 R v$ Jensen, [2000] OJ No 4870, 2000 CarswellOnt 6489 (Sup Ct) [Jensen]; $R v$ Cedano, 2005 ONCJ 91; $R$ v Fleming, 2010 ONSC 8022.

13 McCaw, supra note 6 at para 35. Jensen, ibid, was appealed to the Ontario Court of Appeal on conviction: see Rv Jensen (2005), 74 OR, (3d) 561, 2005 CanLII 7649 (CA). However, the Ontario Court of Appeal did not address the remedy issue.

14 McCaw, supra note 6 at para 54.

15 Ibid.

16 Ibid at para 55.

17 Ibid.

18 Ferguson, supra note 3 at para 40.

19 Ibid at para 65.

$20 \quad R v$ Scarlett, 2013 ONSC 562; $R v$ Hussein, 2017 ONSC 4202.

21 McCaw, supra note 6 at para 76 [emphasis in original].

22 A principle endorsed in the Charter context in Big $M$, supra note 2 .

23 See generally Alexander M Bickel, The Least Dangerous Branch: The Supreme Court at the Bar of Politics (Indianapolis: Bobbs-Merrill, 1962).

24 See Schachter $v$ Canada, [1992] 2 SCR 679 at 695, $93 \operatorname{DLR}\left(4^{\text {th }}\right) 1$ [Schachter].

25 Ferguson, supra note 3 at paras 35, 61.

26 Mackin $v$ New Brunswick (Minister of Finance), 2002 SCC 13 at para 81.

27 Big M, supra note 2.

28 Ferguson, supra note 3 at paras 35, 65.

29 Canada (Attorney General) v Hislop, 2007 SCC 10 at para 83 [Hislop].

30 Sujit Choudhry \& Kent Roach, "Putting the Past Behind Us? Prospective Judicial and Legislative 
Constitutional Remedies" (2003) 21 SCLR 205 at 211 [emphasis in original].

31 Hislop, supra note 29 at para 82.

32 Ferguson, supra note 3 (" $[\mathrm{t}] \mathrm{o}$ the extent that the law is unconstitutional, it is not merely inapplicable for the purposes of the case at hand. It is null and void, and is effectively removed from the statute books" at para 65). See also the comments of McLachlin CJC in $R v$ Nur, 2015 SCC 15 at paras 50-51 [Nur].

33 See Choudhry \& Roach, supra note 30 at 214.

34 Nova Scotia (Workers' Compensation Board) $v$ Martin, 2003 SCC 54 at para 28 [Martin].

35 A declaration of invalidity cannot open previously decided cases (as opposed to pending cases), because those cases have been decided with finality. Two doctrines support this conclusion. First, the de facto doctrine protects any previous applications of an unconstitutional law taken under colour of authority. See Reference Re Manitoba Language Rights, [1985] 1 SCR 721 at 757, 19 DLR $\left(4^{\text {th }}\right) 1$ [Manitoba Reference]: "Thus, the de facto doctrine will save those rights, obligations and other effects which have arisen out of the actions performed pursuant to invalid Acts of the Manitoba Legislature by public and private bodies corporate, courts, judges, persons exercising statutory powers and public officials. Such rights, obligations and other effects are, and always will be, enforceable an unassailable." See also the doctrine of res judicata, which prevents relitigation of cases decided with finality, explained in Regie des rentes $d u$ Quebec $v$ Canada Bread Company Ltd, 2013 SCC 46 at para 29: "Like a binding precedent, an interpretation the legislature adopts by enacting a declaratory provision is applicable to all future cases as well as to cases that are pending when the provision comes into force, despite the fact that the events that gave rise to any such dispute would have taken place before the provision was enacted."

36 Manitoba Reference, ibid at 754.

37 Ibid at 746.

38 Ibid at 753 .

39 Ibid at 754 .

$40 \quad$ Ibid at 757.

$41 \quad$ Ibid at 768.

42 Ibid at 749.

43 Schachter, supra note 24 at 715-16.

44 McCaw, supra note 6 at para 77.

45 Wolfv The Queen, [1975] 2 SCR 107, 47 DLR (3d) 471.

46 Re Residential Tenancies Act, 1979, [1981] 1 SCR 714 at 728,123 DLR (3d) 554.

47 Société canadienne des postes c Bergeron, 2018 QCCS 328. 
